\title{
Virtual Court as Alternative On the Future Criminal Justice System in Indonesia
}

\author{
Aristo Evandy A.Barlian ${ }^{1}$, Annisa D. Permata Herista ${ }^{2}$ \\ \{aristoevandy@ubl.ac.id, nissaherista@yahoo.com\} \\ Lecturer, University of Bandar Lampung, Indonesia ${ }^{1}$, Judge, Lampung District Court, North Lampung, \\ Indonesia $^{2}$
}

\begin{abstract}
The era of digital technology and the presence of the corona pandemic that is currently sweeping the world, has brought drastic changes including the World of Courts. Conventional court practice should turn to Virtual court trials (e-litigation), including Criminal trials. The author deems it necessary to conduct in-depth research on how far the development of e-litigation practices and regulations in Indonesia specifically criminal justice, as well as realizing modern criminal justice in Indonesia. This research uses a normative and comparative approach which is supported by literature study. This research found that since virtual criminal justice was implemented there were many problems ranging from conflicting regulations to its implementation. The problem is caused by not having specific regulations governing the technical e-litigation in Indonesia. The research also found that there are various legal sources that will support the presence of virtual criminal trials in Indonesia. Thus the virtual Criminal Court will later become a renewal of the system to realize modern criminal trials in Indonesia
\end{abstract}

Keywords: Criminal Justice System, Virtual Court, and Renewal of the Legal System

\section{Introduction}

The entry of the digital technology industry 4.0. Marked by the era of the rapid development of information and communication technology, including the judiciary which seeks to innovate and carry out reforms from conventional to virtual trials. Indonesia has started implementing virtual criminal justice based on a policy, namely "Work from Home" as an effort to prevent the spread of the Corona covid-19 virus. The Covid-19 pandemic has caused various problems in various fields of life, including in the law enforcement sector. On the one hand, the Public Prosecutor is obliged to complete handling of criminal cases, but on the other hand there are concerns that a trial that gathers a large number of people will cause the spread of Covid-19. Therefore, courts in Indonesia have now implemented virtual court [1].

The problem with virtual criminal justice in Indonesia is that there is no legality in implementing virtual criminal justice. Virtual criminal justice is only based on circular letters from the Indonesian Supreme Court and cooperation agreements between judicial institutions, while the civil law legal system in Indonesia must have legality in the form of a law. The legality of virtual court in Indonesia only applies to civil courts, but virtual criminal justice does not yet exist [2].

Renewal is a necessity, including renewal of the legal system. The legal system according to Lawrence M. Friedman's [3] theory, namely substance, structure, culture and 
infrastructur, all subsystems must be renewed along with the times. Because it is impossible for justice to be achieved if only one system is repaired, such as justice will be difficult to achieve if the regulations are not good, on the contrary, at best the regulations will not be useful if the law enforcers are not professional, then it becomes a causal relationship in an application of law [4].

To achieve a quality law application, the legal system must also be in line with the goal of the Indonesian state, namely Pancasila [5]. The presence of a virtual court is a sign of the start of a new era of modern justice in Indonesia. Conventional criminal justice in Indonesia requires all parties to be present in court, whereas in the virtual criminal justice system it can be carried out without the presence of the parties. The parties can conduct justice in their respective places. Therefore, it is necessary to reform the criminal procedure law in Indonesia. If you look at other countries such as America, the Netherlands, Australia and the UK, they have implemented virtual court in their countries to support the technological era 4.0 and eradicate the Covid-19.

The background above, it can be seen that in fact virtual criminal justice is a necessity with the existence of a compelling situation in the era of the threat of a global epidemic, besides that, without such compelling circumstances, in fact the era of the technology industry 4.0 is also a challenge for the judiciary to go to modern justice in Indonesia, where justice in the world has use the virtual trial in their respective countries [6]. The Research Purposeis Reforming Criminal Justice System Institutions in Indonesia to be Modern Criminal Court.

\section{Literature Review}

The literature review use Richard Susskind Theory from Oxford United Kingdom about seven of justice priciple, and Muladi Theory From Diponegoro University in Indonesian about Integrated criminal justice system and Lawrence M. Friedman Theory about legal substance, legal stuckture than legal culture.

\section{Methods}

The research methodology in this paper is a qualitative normative legal research. In normative legal research using several approaches, namely the statutory approach, conceptual approach, and the comparative approach. By using this qualitative normative method in this research is related to the legal approach and approach to the problem. Analysis on qualitative normative in this research is based on descriptive and predictive analysis.

\section{Result}

\subsection{Virtual Court As A New Culture For The Future Court In Indonesia}

The Covid-19 outbreak has paralyzed community activities in various sectors, including in the legal perspective. Trial activities are also affected by various problems due to the Covid-19 pandemic, namely in criminal proceedings on the grounds that the limited period of detention is the basis for the Indonesian Supreme Court to establish a virtual trial in accordance with the Regulation of the Supreme Court of Indonesia Number 1 of 2019 concerning trial procedures electronics, but not in criminal justice [7]. 
The application of Virtual Criminal Justice is something that can be seen as progressive for the judiciary in Indonesia which has now begun to be established at the time of the threat of the Covid 19 outbreak. In accordance with the principle of justice "fast, simple, and low cost, this is a very positive concept for the future. Another thing that can be learned from the digital trial is that it can save time because you don't have to wait for the defendant to come to the court. This must be the concern of the Supreme Court of Indonesia so that in the future it can be followed up not only through institutional cooperation but also through Supreme Court Regulations or statutory regulations. This can be made in addition to adjustments in the District Court, such as the implementation of the virtual system in the Police, Attorney General's Office and other legal institutions [8].

The digital justice system due to the corona virus disease can continue and be integrated, not only the trial but the entire case system should also be able to implement an online system. Regarding the online trial, further regulation is needed, and must have the necessary tools and specific evidence. For example, in the reading of indictments or the verification process, documents can be done digitally, but if you present the evidence in Indonesia, they are still present in person so that there are no distortion errors, it can be judged that the implementation of this online trial must have a judicial technical basis for the judicial process through a special regulation [9].

The virtual system policy in the judiciary embodies progress from the principle of fast, simple, and low cost. This cuts unnecessary bureaucratic chains and prevents deviant practices in the judiciary. This electronic trial is an adaptation change that must be accepted and carried out, because the world of information technology has developed. Adaptation to the digitalization of justice is needed in the new normal conditions that will come in the pattern of working relationships between humans for the life to come [10].

The development of a virtual-based modern justice system, it is hoped that a transparent and accountable court will be created. Dory Reiling said there were three main problems faced by judicial institutions around the world, namely the slow handling of cases (delay), difficulty in public facilities and access (access), and the integrity of the court apparatus (judicial integrity). Thus the use of technology in the world of justice will solve problems in conventional justice [11].

In the implementation of Virtual court, infrastructure is also an important discussion because if it is not adequate then it will clearly have implications for not fulfilling justice for the community. Virtual court as the application of law requires renewal in terms of infrastructure. The responsiveness of the judiciary to fulfill public justice is the main thing. It is intended that access to justice can be wide open for fulfillment for the entire community [12].

In carrying out judicial functions, law enforcers in this case also have essential duties, namely justice (gerechtigheit), benefit (zwachmatigheit) and certainty (rechsecherheit). Law enforcers as the main organ in a court and as judiciary executors such as demanding, accepting, examining, and adjudicating a case must have a concept of professionalism, namely in terms of creativity, innovation, and responsiveness [13].

The presence of virtual criminal justice, it will improve the user experience for justice seekers. Virtual criminal justice is also an opportunity to defend oneself (audi et alteram partem). The application of an online system provides broad access for Parties to submit their defense so as to provide more protection for the parties. Likewise, the application of electronic case administration will leave a digital trace that is stored forever so that in addition to being controlled by the public, it can also prevent files from being lost or damaged [14]. 
Through the application of virtual trials, it is hoped that in the future public trust and access to all court institutions and law enforcement officials will continue to increase. This is in line with what Stephan Golub stated, that a very important element in access to justice is that the existence of a formal legal institution should be the place most trusted by the community as an efficient, neutral and professional institution. According to Gollub, public satisfaction and trust in formal institutions is very important. Thus the presence of the virtual court system as a new culture is part of the court's efforts to provide easy access to the public and justice seekers as well as efforts to make courts more integrated, accountable, transparent, effective and efficient [15].

In line with the development of digital technology, the transformation of the court which is expected to become a modern court by utilizing digital information technology will be achieved. The upcoming criminal virtual court will also fulfill the sense of justice of all parties, which according to Richard Susskins consists of 7 (seven) principles of justice, namely Substantive justice, which contains fair decisions, Procedural justice, which contains a fair process for all parties, Open justice namely transparent and open to all people, Distributive justice, which is a system that can be accessed by all parties without exception, Proportionate justice, namely a proportionate sense of justice that is proportionate to all parties appropriately, Enforceable justice, which is supported by all parties, especially in state law, Sustainable justice, namely contain sufficient resources in continuous change so that it continues to be the best [16].

There is a legal comparison which is one of the studies of legal science to find novelty in the current system, so a comparison is needed to become a benchmark for the formation of a new system that is in accordance with expectations and needs. There are several countries that have used an online justice system, namely: [17]

Table 1. Comparation Of Virtual Court System

\begin{tabular}{lll}
\hline Country & \multicolumn{1}{c}{ Law } & \multicolumn{1}{c}{ Term } \\
\hline Australia & High Court Bulletins 1996 & E-Justice \\
Amerika & Public Act 262 of 2001 America & Cyber Court \\
Belanda & Act 78a and 131a Straafvoerdering & $\begin{array}{l}\text { Remote } \\
\text { justice }\end{array}$ \\
England & $\begin{array}{l}\text { Criminal Justice 1988 act 32 and Statute Roma } \\
\text { act 68 (2). }\end{array}$ & Digital Court \\
Singapura & The Evidence Act 97 & Virtual Court \\
\hline
\end{tabular}

Legal reform here means that the judicial institution must be able to explore, reconstruct, and capture the substance of justice that is increasingly evolving in society and then gives it back to society in the form of court decisions that focus on justice, certainty and legal benefits [18]. Of course the direction of this reform must support the country's development programs, besides that in terms of policy, reform of criminal law must be able to strive to balance various interests and protection of rights. The guarantee of protection of human rights in the 
constitution, the development of international human rights norms and democratic values, are important factors in influencing a country's criminal law policy [19].

Therefore, to realize indonesia virtual court, effective and efficient steps are needed from the beginning of the entry of cases in the criminal justice system so that courts, especially at the first level, are able to serve the interests of the community, which is marked by low-cost judicial processes, simple judiciary, and trials with time to settle cases. fast and accurate.[20] Because in general, time standards are measures of efficiency and effectiveness set by courts and other institutions to support performance standards and indicators that aim to ensure efficient process and accountability [21].

\subsection{The Future Of Indonesian Virtual Criminal Court.}

The application of virtual court directly impacts on the efficiency of judicial administration as well as the transparency of the justice-seeking process that encourages professional, transparent, accountable, effective and efficient law enforcement behavior. Modernization and judicial reform have resulted in the slow settlement of case handling and increased integrity and professionalism of law enforcement officials. The direct impact felt by justice seekers themselves is through the application of their own virtual court system which actually makes it easier for the justice-seeking community to access and control the ongoing process as well as to save on court costs [22].

Information technology is a necessity that cannot be denied, however, according to the author's view; it must still comply with the legality of Indonesian criminal procedure law, such as in the substantial and procedural aspects. The novelty in the Substantial aspect is to create legal norms in virtual criminal court such as regulations of the Supreme Court or laws and regulations that at least explain in "certain circumstances" can choose or use virtual court. Then on the novelty of the procedural aspect, namely in the form of guidelines for the implementation of virtual court in criminal cases which are based on procedural law which accommodates the interests of the parties ranging from judges, public prosecutors, legal advisors, defendants, and witnesses / experts and other principles of procedural law [23].

The aim of modernizing the judiciary in Indonesia is to provide quality, effective and efficient services to justice seekers. To achieve quality legal services, every legal system must be in line with the times, because it is impossible for the legal process to be achieved properly if only one system is improved such as law enforcement will have difficulty achieving justice and enforcing the law if the legal regulations are still inadequate, vice versa. as best as possible the established legal regulations will not be useful if the law enforcers are not professional, then it becomes a causal relationship in the application of law to build a legal system that is in line with the needs and developments of the times [24].

In reforming criminal law, Indonesia recognizes the development of sub-systems in criminal law, namely the development of structure, substance and culture. The construction of the structure is by updating the online model for law enforcers and also all related parties such as Judges, Prosecutors, Advocates, Witnesses, Experts, accused victims and other parties. Whereas in the development of substance is the renewal of a norm or regulation such as lax generals, namely criminal procedure law and implementing regulations such as the Supreme Court Regulations. Then in the development of culture in virtual court is a renewal of infrastructure and renewal that follows the current cultural conditions and habits of society, finally it is necessary to renew infrastructure which will also support the running of virtual court in the future. This is what must be completed in Indonesia's future national legal system. 
Virtual sessions should be reformed in accordance with the needs of the current era which cannot be avoided and can be followed by all parties, but because they are aware of the many weaknesses and shortcomings, virtual sessions are actually an alternative form of judicial implementation that may be carried out online if there are certain circumstances and the importance of the agreement of all parties in the case going forward.

The existence of virtual criminal justice can at least fulfill substantially to be carried out properly if it is formulated in a Supreme Court Regulation or Legislation. With the existence of clear regulations in the implementation of virtual crimes, virtual criminal justice will not be a problem and anxiety in the community and justice seekers. In addition, the concept of virtual criminal will be in accordance with the values that exist in Pancasila, especially in accordance with the 5th precept, namely social justice for all Indonesian people, with a system that can accommodate all the wishes of the community. It is said that in accordance with the values of Pancasila, the criminal justice court in Indonesia will be more godly, humane, united, democratic and socially just.

Referring to the upcoming virtual criminal justice will also further realize the principle of fast justice, simple low cost, this principle is also in line with the values of Pancasila in Indonesia. It can be assessed that later the application of the virtual criminal system will also create a speedy trial without any obstacles, disturbances and delays in any form. Virtual court will also be simpler, easier, more sophisticated, less complicated by bureaucracy and can be followed by all Indonesians. Then virtual court will also not cost much and will not take much time for justice seekers. The aim of modernizing the judiciary in Indonesia is to provide quality, effective and efficient services to justice seekers. To achieve quality legal services, every legal system must be in tune with the times.

Philosophically, the existence of a virtual criminal justice will improve justice and provide protection for the rights of the parties as well as significant convenience in the judicial process. Sociologically, the existence of virtual criminal justice is a form of presence that has been awaited in meeting the needs of society in this technological era through virtual criminal justice. Juridically, the existence of virtual criminal justice is as a lex generalist, namely the principle of judicial power and as a lex priori in the current judicial regulations, which will soon be obeyed and implemented without any turmoil from any party.

Regulations related to virtual criminal justice in Indonesia must be formed as soon as possible because given the emergency era of the outbreak and the demands of the era of technological advancement. At least the regulations related to virtual criminal justice are formed through the regulations of the Indonesian Supreme Court that apply generally to the whole community or the formation of new procedural law regulations that explain alternatives to criminal justice through vitual, for the modern future court in Indonesian.

\section{Conclusion.}

It can be concluded that virtual criminal trials currently do not have a firm legal basis and cause many problems both from a regulatory perspective and from a practical perspective. If the current virtual criminal trial continues to use the basis of circular and state agency cooperation agreements that are not general regulations, then the judiciary will find it difficult to create justice and legal certainty that benefits all Indonesian people. The trial must reflect the values of Pancasila and the principles of good procedural law in accordance with the expectations and developments of the times. The practice of virtual trials in Indonesia must have regulations to be able to create justice, certainty and benefit. Virtual trials are a challenge and a necessity that justice seekers have been waiting for in order to get a more effective and 
efficient justice service. Currently, law outside countries such as America, Australia, the Netherlands, Singapur and the UK have also used the Virtual criminal justice system. With the presence or absence of Covid 19 in Indonesia, the virtual criminal trial should still be prepared as an alternative effort in certain circumstances, so as to realize modern justice for the future of Criminal Justice in Indonesia.

\section{References}

[1] Amran Suadi : The Role of Law Enforcement Agencies in Dynamics and Law in the Digital Age", Journal Varia Pengadilan hukum of XXXIII No. 391 Juni (2018).

[2] RR. Dewi Anggraeni : The Covid-19 Pandemic Outbreak, The Urgency to Conduct Electronic Sessions, Journal Buletin Hukum dan Keadilan, Vol 4, No 1, Juni (2020).

[3] Lawrence M. Friedman: The. Legal System: A Sosial Science Perspektive, by Syarif, Nusa Media, Bandung, (2009)

[4] Barlian, Aristo Evandy A.Formulasi Ide Permaafan Hakim (RECHTERLIJK PARDON) dalam Pembaharuan Sistem Pemidanaan di Indonesia, Journal Law ReformUndip, Vol. 13 No. 1, Semarang (2017).

[5] Barda Nawawi Arief :Indonesia Development Legal System, On Program Magister Ilmu Hukum Pascasarjana UBH, Padang, (2009).

[6] Supriyadi W. Eddyono : Providing Witness Information through Videoconference in Criminal Drafts. Institute for Criminal Justice Reform, Institute for Criminal Justice Reform. (2015).

[7] Suhadi : Electronic Criminal Court Trial Administration, Jakarta. (2020).

[8] Anthony Garofano : Avoiding Virtual court : Video-Teleconference Testimony in Federal Criminal Trials, Catholic University Law Review, Volume 56, Issue 2, (2007).

[9] Fredric I. Lederer : The Road to the Virtual Courtroom? A Consideration of Today's - and Tomorrow's- High Technology Courtrooms, Virginia, Faculty Publications - William and Mary Law. School Scholarship Repository,Virginia(2001).

[10] Anggita Doramia Lumbanraja : Development of regulations and the Implementation of the Indonesian Online Court, Journal Crepido Dasar Pemikiran Hukum, Volume 02,Nomor 01, (2020).

[11] Dory Reiling : Technology for Juctice: How Informaton Technology Can Support Judicial Reform, Leiden University Press, (2009).

[12] Lucille M. Ponte : Michigan Cyber Court: A Bold Experiment in the Development of the First Public Virtual Courthouse, North Carolina Journal of Law and Technology, Volume 4, Issue 1, January. (2002).

[13] Paul Stothard, Clinton Slogrove : COVID-19 approach to court proceedings, Norton Rose Fulbright LLP, International Law Office, (2020).

[14] Rio Satria : E-Litigation in Indonesia, Articel Badilag. (2019).

[15] Stephan Golub : Beyond Rule of Law Orthodocy : The Legal Empowerment Alternative, "Rule of Law series, Journal Democracy and Rule of Law Project, Oxfort. (2003).

[16] Richard Susskind : Online Court and Futuer of Justice, Oxford. United Kingdom, (2019).

[17] Anna wallace on Marco : Fabri, E-JUSTICE, Using Information Communication Technologies in the Court System, Information Science Reference, Hershey New York, (2009).

[18] Hamish Ross : Law as a Social Institution, Hart Publishing, Oregon(2001).

[19] Adriaan Bedner : Court Reform, University Press, Leiden (2008)

[20] Barlian, Aristo Evandy A. Konsistensi Pembentukan Peraturan Daerah Berdasarkan Hierarki Perundang-Undangan dalam Perspektif Politik Hukum. Fiat Justisia: Jurnal Ilmu Hukum, Universitas Lampung, 10(4), (2016).

[21] Michael Tonry : Penal Reform in Overcrowded Times, Oxford University Press, (2001).

[22] Fazrie Mohammad : Analysis Performance Video Conference use Codec H264 Baseline and H264-High Profile with integration Enskripti, IncomTech, Journal Telecomunication andComputer. (2017). 
[23] Voermans : Wim Judicial Transparency Furthering Public Accountability For New Judiciaries, Volume 3, Issue 1,(2007).

[24] AEA.Barlian, Development of Legal System in Indonesia that based on the Value Pancasila, Journal Muhammadiyah Law Review, Vol 1 No.2 (2017). 